\title{
Studies on Peripheral Glucose Metabolism Using the Experimental Human Forearm Preparation
}

\author{
G.A. Zampa, F. Altilia, D. Bracchetti, G.D. Grimintant, E. Borgatti and M.T. Odifreddi
}

The Institute of Medical Pathology of the Bologna University, S. Orsola Hospital, Bologna, Italy

(Director: Prof. D. Campanacci)

Received July 27, 1966

Summary. Metabolic studies on the human forearm glucose uptake are described. The results of these investigations can be summarized as follows: the mean fasting forearm glucose uptake of normal subjects was found to be $+0.53 \mu \mathrm{mol} / \mathrm{min} / 100 \mathrm{ml}$ of forearm (S.E. \pm 0.20 ), of fasting insulin-dependent diabetics $-0.32 \mu \mathrm{mol} / \mathrm{min} / 100 \mathrm{ml}$ of forearm (S.E. + 0.59 ) and of fasting insulin-independent diabetics of $-0.50 \mu \mathrm{mol} / \mathrm{min} / 100 \mathrm{ml}$ of forearm (S.E. +0.23 ). - Statistical analysis of these data show that in 3 insulin-dependent diabetic patients there is a significant correlation between arterial blood glucose and forearm glucose uptake pointing to a peripheral tissue threshold above which the glucose molecule moves from the intravascular space to the intracellular compartment. - No significant correlations were found between the deep venous blood glucose of the forearm and the forearm glucose uptake in the same patients. - The injection of 0.1 units glucagon-free insulin into the brachial artery increases the forearm glucose uptake without affecting the arterial blood glucose. Greater doses decrease the arterial blood glucose inhibiting the hepatic glucose output. - On the other hand in the insulin-dependent diabetics no peripheral insulin effect was shown with the same or higher insulin doses indicating that these patients may have a peripheral tissue resistance to the insulin action. - The mean average forearm phosphate uptake was estimated to be $+0.03 \mu \mathrm{mol} / \mathrm{min} / 100 \mathrm{ml}$ of forearm (S.E. 士 0.04 ) in normals and $-0.03 \mu \mathrm{mol} / \mathrm{min} / 100 \mathrm{ml}$ of forearm (S.E. +0.13 ) in diabetics. Furthermore the statistical analysis of these data showed that there is a significant relationship $(P<0.05)$ between the forearm glucose uptake and the forearm phosphate uptake both in normals and in diabeties. This should mean that the phosphate molecule follows the glucose molecule moving from the extracellular space to the intracellular space according to the insulin effect. - Finally the mean fasting forearm potassium uptake was $-0.93 \mu \mathrm{mol} / \mathrm{min} / 100 \mathrm{ml}$ of forearm (S.E. \pm 0.45 ) in normals and $-0.90 \mu \mathrm{mol} / \mathrm{min} / 100 \mathrm{mI}$ of forearm (S.E. \pm 2.7 ) in diabetics. No significant correlations were found botweon the forearm glucose uptake and the potassium glucose uptake in either normals or diabetic patients.

Etudes sur le métabolisme périphérique du glucose à l'aide de la préparation expérimentale de l'avant-bras humain.

Résumé. Les auteurs décrivent des études métaboliques sur la captation du glucose par l'avant-bras humain. Les résultats de ces investigations peuvent être résumés comme suit: La captation moyenne de glucose par l'avantbras de sujets normaux à jeun, était de $+0.53 \mu \mathrm{mol} / \mathrm{min} /$ $100 \mathrm{ml}$ d'avant-bras (S.E. \pm 0.20 ), celle des diabétiques insulino-dépendants à jeun était de $-0.32 \mu \mathrm{mol} / \mathrm{min} /$ $100 \mathrm{ml}$ d'avant-bras (S.E. \pm 0.59 ) et celle des diabétiques non-insulino-dépendants à jeun, était de $-0.50 \mu \mathrm{mol} /$ $\min / 100 \mathrm{ml}$ d'avant-bras (S.F. $\perp 0.23$ ). - Les analyses statistiques de ces données montrent que chez 3 patients diabétiques insulino-dépendants, il y a une corrélation significative entre la glycémie artérielle et la captation de glucose par l'avant-bras, indiquant qu'il y a un seuil dans le tissu périphérique au-dessus duquel la molécule de glucose passe de l'espace intravasculaire dans le compartiment intracellulaire. - Chez les mêmes patients, on n'a trouvé aucune corrélation significative entre la glycémie de la veine profonde de l'avant-bras et la captation de glucose par l'avant-bras. - L'injection dans l'artère brachiale de 0.1 unité d'insuline sans glucagon augmente la captation de glucose par l'avant-bras sans modifier la glycémie artérielle. Des doses plus élevées diminuent la glycémie artériellle en inhibant la production de glucose hépatique. - D'autre part, chez les diabétiques insulinodépendants, il ne se produisait aucun effet périphérique de l'insuline, avec des doses d'insuline égales ou supérieures, ce qui indique que ces patients peuvent avoir une résistance des tissus périphériques à l'action de l'insuline. - La captation moyenne de phosphate par l'avant-bras a été estimée être de $+0.03 \mu \mathrm{mol} / \mathrm{min} / 100 \mathrm{ml}$ d'avant-bras (S.E. \pm 0.04 ) chez les sujets normaux, et de $-0.03 \mu \mathrm{mol} /$ $\mathrm{min} / 100 \mathrm{ml}$ d'avant-bras (S.E. \pm 0.13 ) chez les diabétiques. En outre, l'analyse statistique de ces données a montré qu'il y a une relation significative $(P<0.05)$ entre la captation de glucose et la captation de phosphate par l'avant-bras, aussi bien chez les sujets normaux que chez les sujets diabétiques. Ceci signifierait que la molécule de phosphate suit la molécule de glucose passant de l'espace extracellulaire dans l'espace intracellulaire, sous l'effet de l'insuline. - Enfin, la captation moyenne de potassium par l'avant-bras était, à jeun, de $-0.93 \mu \mathrm{mol} / \mathrm{min} / 100 \mathrm{ml}$ d'avant-bras (S.E. $\neq 0.45$ ) chez les sujets normaux, et de $-0.90 \mu \mathrm{mol} / \mathrm{min} / 100 \mathrm{ml}$ d'avant bras (S.E. \pm 2.7 ) chez les diabétiques. On n'a trouvé aucune corrélation significative entre la captation de glucose et celle de potassium par l'avant-bras, ni chez les sujets normaux, ni chez les diabétiques.

Untersuchungen über den peripheren Glucosestoffwechsel am menschtichen Unterarm.

Zusammenfassung. Es werden Untersuchungen der Glucoseaufnahme am menschlichen Unterarm beschrieben. - Die Untersuchungsergebnisse können, wie folgt, zusammengefaßt werden: Die durchschnittliche GlucoseAufnahme am Unterarm im Nüchternzustand lag beim Normalen bei $+0.53 \mu \mathrm{mol} / \mathrm{min} / 100 \mathrm{ml}$ Unterarm (S.E. \pm 0.20 ), bei insulinabhängigen Diabetikern bei -0.32 $\mu \mathrm{mol} / \mathrm{min} / 100 \mathrm{ml}$ Unterarm (S.E. +0.59 ) und bei nicht insulinbediurftigen Diabetikern bei $-0,50 \mu \mathrm{mol} / \mathrm{min} /$ $100 \mathrm{ml}$ Unterarm (S.E. \pm 0.23 ). - - Die varianzanalytische Betrachtung dieser Ergebnisse zeigt für 3 insulinbedürftige, diabetische Patienten eine signifikante Korrelation zwischen arteriellem Blutzuckerspiegel und der Glucoseaufnahme am Unterarm und deutet damit auf das Vor. liegen eines Schwellenwertes im peripheren Gewebe hin, bei dessen Überschreiten das Glucosemolekiil aus dem intravaskulären Raum in den Intrazellulärraum eintritt. - Dieselben Patienten zeigten keine signifikante Korrelation zwischen dem Blutzuckerspiegel in den tiefen Venen und der Glucoseaufnahme des Unterarms. - Die Injektion von $0.1 \mathrm{E}$ glucagonfreiem Insulin in die A. brachialis steigert die Glucose-Aufnahme am Unterarm, ohne den arteriellen Blutzuckerspiegel zu beeinflussen. 
Höhere Dosen senken den arteriellen Blutzuckerspiegel durch Hemmung der Glucoseausschüttung der Leber. Bei den insulinbedürftigen Diabetikern fand sich jedoch mit den gleichen oder höheren Insulin-Dosen kein peripherer Insulin-Effekt, so daß die Annahme nahe liegt, daß bei diesen Patienten das periphere Gewebe eine Resistenz gegenüber der Insulinwirkung aufweist. Die durchschnittliche Phosphat-Aufnahme am Unterarm lag schätzungsweise bei $+0.03 \mu \mathrm{mol} / \mathrm{min} / 100 \mathrm{ml}$ Unterarm (S.E. \pm 0.04 ) für die Normalpersonen und bei -0.03 ) $\mu \mathrm{mol} / \mathrm{min} / 100 \mathrm{ml}$ Unterarm (S.E. \pm 0.13 ) für die Diabetiker. Die statistische Auswertung der Resultate ergab eine signifikante Abhängigkeit ( $p$ kleiner als 0.05 ) zwischen Glucose- und Phosphat-Aufnahme am Unterarm bei Normalpersonen und Diabetikern. Dies würde bedeu- ten, daß das Phosphat-Molekül dem Glucose-Molekül folgt, das unter der Insulin-Einwirkung aus dem Extrazellulärraum in den Intrazellulärraum übertritt. Schließlich lag die Kalium-Aufnahme des Unterarms im Nüchternzustand für die Normalpersonen bei $-0.93 \mu \mathrm{mol} /$ $\min / 100 \mathrm{ml}$ Unterarm (S.E. \pm 0.45 ) und für die Diabetiker bei $-0.90 \mu \mathrm{mol} / \mathrm{min} / 100 \mathrm{ml}$ Unterarm (S.E. \pm 2.7). Weder bei den Kontrollpersonen noch bei den Diabetikern ergab sich eine signifikante Korrelation zwischen Glucose- und Kalium-Aufnahme am Unterarm.

Key-words: Forearm glucose uptake, phosphate potassium, arterio-deep venous differences, forearm blood flow, diabetes mellitus.
Peripheral glucose metabolism has usually been evaluated in man in vivo by means of arterio- or capillary-venous glucose differences, which are assumed to be an index of glucose uptake, mainly of the skeletal muscles.

However the peripheral tissue uptake or output of many metabolites can be measured with more accuracy by the application of the Fick principle, taking into account not only the arterio-venous difference of the metabolic compound but also the blood flow which perfuses the organ or the anatomical territory involved.

From the quantitative point of view these measurements are preferable for the following reasons:

1. the arterio-venous difference of a metabolite depends upon either the metabolic activity of the tissue substrate, and the hemodynamic changes of its circulatory system;

2. for tissue balance investigation and comparative metabolic studies, it is more efficient to work out quantitative data per minute and per tissue weight or volume.

Therefore in order to get quantitative information about glucose metabolism of human skeletal muscles in vivo, the forearm was adopted as the more suitable experimental working model for tissue uptake estimations (ANDRES et al., 1956; ButTERFIELD and Holling, 1959; Zampa et al., 1962a).

This was suggested by the following anatomical and physiological observations:

a) the human forearm is mostly a muscular organ, 60-70 per cent W/W (ABRAMSON and FERRIS, 1940; Cooper et al., 1955);

b) approximately 85 per cent of the forearm blood flow is muscular blood flow (BALTZAN et al., 1962);

c) the anatomical device of the human forearm provides an experimental preparation where arterial and deep venous blood samples can be easily obtained contemporaneously with blood flow measurements (Mottrami and Buttarfield, 1961; Zampa et al., $1962 b)$.

Two techniques have been used for measurements of the forearm blood flow; both are suitable for forearm glucose uptake estimation: a) dye-dilution technique (ANDRes et al., 1954) and

b) venous occlusion plethysmography (GREENFIELD and Patterson, 1954).

The purposes of the present investigation were:

1. to measure the forearm glucose uptake in normal subjects and in patients with diabetes mellitus, in fasting and resting conditions,

2. to study the insulin effect on human skeletal muscles in vivo, and

3. to examine the relationship between glucose uptake and phosphate and potassium uptakes, both in normal people and in those with diabetes mellitus.

\section{Materials and Methods}

We examined 41 subjects: 22 were patients with minor illnesses who did not show any metabolic, endocrine or stressing diseases, 13 were diabetics, 4 were thyrotoxic and 2 had clear-cut hypothyroidism.

Of the normal group 15 were males ranging in age from 15 to 60 years and in weight from 50.2 to $76.5 \mathrm{~kg}$, 7 were females ranging in age from 15 to 49 years and in weight from 49.0 to $67.5 \mathrm{~kg}$.

The 13 diabetic patients were divided into 5 insulin-independent and 8 insulin-dependent: the latter showed frank ketosis upon insulin withdrawal. The former never had ketosis, were plump, and well controlled with diet only. Of the 13,7 were males ranging in age from 28 to 61 years and in weight from 50.5 to $78.5 \mathrm{~kg}$.

Of the thyrotoxic group there were 2 males and 2 females, both hypothyroids were male.

The ages of this group ranged from 22 to 48 years and the weights from 52 to $72.5 \mathrm{~kg}$.

All the subjects were examined in the morning between 9.30 and $10.0 \mathrm{a} . \mathrm{m}$. resting in bed.

1. Technique to perform simultaneously, forearm blood flow measurements, blood sampling from the brachial artery and a deep vein of the forearm

Our previous experiments (ZAMPA et al., 1962b) indicated that glucose injected in the brachial artery perfuses the forearm muscles and reaches its maximum concentration in the deep venous blood after $35-40$ 
sec. However, the glucose load $(100 \mathrm{mg})$ injected into the brachial artery reaches the deep venous territory in 10 sec. and leaves it completely within $120 \mathrm{sec}$. On this experimental basis it was thought necessary to carry out the arterial and venous sampling together with the forearm blood flow measurements within $60 \mathrm{sec}$.

a) Arterial and venous blood samples: we obtained arterial blood using a Cournand needle inserted into the brachial artery towards the blood flow and connected by means of a polyethylene catheter, through a tap, to a syringe. The venous blood was collected from a deep vein draining the skeletal muscles of the forearm. Both the Cournand's needle and the deep vein catheter were kept patent by frequent small perfusions of heparinized saline $(2 \mathrm{ml}$ of heparin in $1000 \mathrm{ml}$ of saline).

b) Forearm blood flow estimation. The forearm blood flow was measured by means of an occlusion plethysmographic technique. We used a water plethysmograph and an electric transducer as a volume change detector. Thermostatic means controlled the plethymograph at $32^{\circ} \mathrm{C}$ and the hand circulation was excluded from the system.

The transducer placed in the water column of the plethysmograph detects very small fluctuations of the water level and transforms them into electrical signals which are then magnified by a carrier amplifier and finally recorded by means of a common electrocardiograph with a. D.C. inflow.

Our transducer (ALTiLTA et al., 1962) consists of 2 silver wires immersed in water, constituting a branch of a Wheatstone bridge fed by alternating current. Varying the water level alters the resistance of the system so one can have variations of the outflow signals with a very low level inflow signal. The sensitivity of our system is very high $(2.5 \mathrm{~cm}$ in written and $8 \mathrm{~cm}$ in photographic recordings for $10^{-2} \mathrm{~mm}$. liquid level change) and shows a good linear response of \pm 5 per cent. This sensitivity corresponds, in a plethysmograph, with a tube $3 \mathrm{~cm}$ in diameter, to an increase of the volume of the limb segment contained in the plethysmograph of $76 \times 10^{-3} \mathrm{ml}$.

c) Preparation of the experimental forearm for metabolic investigation. The patient is examined in bed lying on his back.

Using a very thin needle 2 per cent xylocaine is injected into soft tissue around the brachial artery and around a suitable superficial vein of the anterior aspect of the elbow. A needle is then inserted into the superficial vein in connection with the deep venous territory and through it a polyethylene is placed in the deep vein at a depth of about $6-8 \mathrm{~cm}$. A Cournand needle is then introduced into the brachial artery. The position of the catheter in the deep vein is then radiographically checked and adjusted (Fig. 1).

The plethysmograph is placed around the forearm, filled with water and left to stabilize at $32^{\circ} \mathrm{C}$. A cuff $5.0 \mathrm{~cm}$ wide is placed around the arm, $8-10 \mathrm{~cm}$ above the elbow and connected with a mechanical arrangement suitable to introduce and release alternately and very rapidly a pressure of $60 \mathrm{mmHg}$.

When inflating the cuff with a pressure higher than the venous pressure and lower than the diastolic arterial pressure, blood can get into the forearm but is trapped in the territory distal to the occluding cuff.

During the first period of the venous occlusion, the volume of the forearm increases progressively according to a straight line, from which the blood flow of the segment of the forearm contained in the plethysmograph can be estimated.

The hand is excluded from the system using a cuff around the wrist inflated to a pressure of $250-$ $300 \mathrm{mmHg}$.

Finally the transducer is placed into the water column and several calibration curves are carried out (Fig. 2).

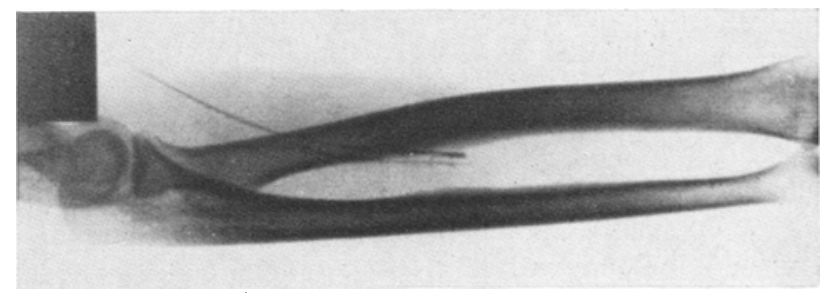

Fig. 1. X-Ray of the human forearm: demonstrating the correct position of the catheter placed in a deep vein of the forearm

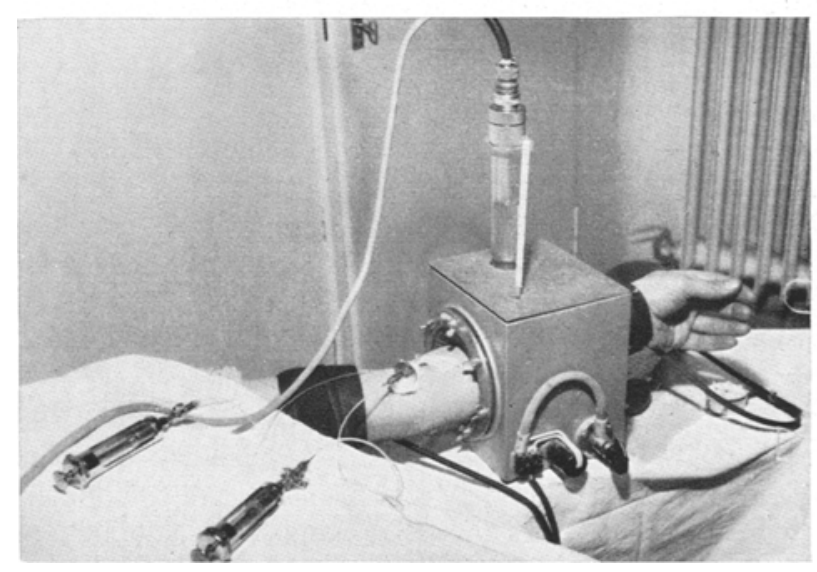

Fig. 2. The human forearm experimental preparation set up for metabolic investigation

The complete procedure is performed as follows:

1. the heparinized saline perfusions are stopped and the taps of the arterial and venous catheters closed;

2. after 20 sec the forearm blood flow is measured in $8-15 \mathrm{sec}$;

3. 2-3 sec. after the end of the 2 nd step the blood and saline mixture left in both the catheters are suctioned off and the arterial and venous blood samples are simultaneously drawn; 
4. 4-5 sec after the end of the blood sampling, a second blood flow estimation is carried out.

Under basal conditions several measurements were performed during periods varying between 15 and 120 minutes.

\section{Biochemical techniques}

a) "True" blood glucose has been determined by the gluco-oxidase method of Huggett and Nixon (1957);

b) Plasma phosphate has been determined by the method of Fiske and Subbarow (1925);

c) Plasma potassium has been determined using flame spectrophotometry.

All these determinations were carried out in duplicate on the same blood sample.

The differences in duplicate determinations of "true" blood glucose were accepted when less than $1 \%$ of the average.

\section{Forearm uptake calculation}

Based on the fact that we wanted to be as certain as possible of making our calculations only from forearm muscular blood flow we accepted only the observations of less than $6.5 \mathrm{ml} / \mathrm{min} / 100 \mathrm{ml}$ of forearm blood flow since figures higher than this would mean that cutaneous blood flow was also involved (Cooper et al., 1955).

Using the Fick principle, glucose, phosphate and potassium muscular uptakes of the forearm have been worked out as follows:

$$
C=F \times \Delta a-v
$$

where

$C \quad=$ forearm uptake

$F=$ forearm blood flow

$\Delta a-v=$ arterio-venous blood glucose (or phosphate or potassium) difference.

Our calculations for these experiments have been made using $\mu \mathrm{mols} / \mathrm{min} / 100 \mathrm{ml}$ of forearm for all three substances considered.

\section{Insulin effect on skeletal muscles}

We have also injected $4.0-1.0-0.25-0.15-0.10$ and 0.01 units of glucagon-free insulin into the brachial artery of 8 normal subjects and of 6 diabetics (5 insulin-dependent and 1 insulin-independent), in order to study the insulin effect on muscular glucose metabolism.

After several forearm glucose uptakes were estimated under basal conditions, a single dose of glucagonfree insulin was rapidly injected into the brachial artery and the forearm muscular glucose uptake measurements were again carried out every 10 minutes for a 50 minute period.

The hand was kept excluded from the system throughout the experiment, with 5 minutes rest every 15 minutes.

1 Glucagon-free insulin Lilly-Lot N. W-3691 T.
Results

All our results are set out on table 1.

\section{Forearm glucose uptake}

a) Normals. After 12-14 hours of fasting, both the arterial and the deep venous blood glucose concentrations of the forearm show spontaneous fluctuations. The mean average of the arterial blood glucose is $4.72 \mathrm{mmol} / \mathrm{l}$ (S.E. \pm 0.26 ) and the mean average of the deep venous blood of the forearm is $4.55 \mathrm{mmol} / \mathrm{l}$ (S.E. \pm 0.26 ).

The mean average of the arterio-deep venous glucose differences is $+0.17 \mathrm{mmol} / 1$ (S.E. \pm 0.21 ). Of the 22 cases examined, 15 show positive and 7 negative values.

The mean forearm blood flow ranges from 1.64 to $4.28 \mathrm{ml} / \mathrm{min} / 100 \mathrm{ml}$ of forearm, giving a mean average of $3.11 \mathrm{ml} / \mathrm{min} / 100 \mathrm{ml}$ of forearm (S. E. \pm 0.22 ) These figures are in the range of the values calculated from a group of 60 normal subjects having a cardiac rate of less than 90 pulsations per minute, which are in between 1.24 to $4.46 \mathrm{ml} / \mathrm{min} / 100 \mathrm{ml}$ of forearm with a mean of $2.5 \mathrm{ml} / \mathrm{min} / 100 \mathrm{ml}$ of forearm (S.E. \pm 0.06 ).

The forearm glucose uptake of this group ranges from -1.13 to $+2.93 \mu \mathrm{mol} / \mathrm{min} / 100 \mathrm{ml}$ of forearm with a mean average of $+0.53 \mu \mathrm{mol} / \mathrm{min} / 100 \mathrm{ml}$ of forearm (S.E. \pm 0.20 ).

b) Diabetics. In fasting and resting conditions the arterial blood glucose of the insulin-dependent group range from 10.37 to $25.17 \mathrm{mmol} / \mathrm{l}$ with a mean of $16.06 \mathrm{mmol} / \mathrm{l}$ (S.E. \pm 2.0 ), while the deep venous blood glucose of the forearm range from 10.79 to 24.58 with a mean of $16.16 \mathrm{mmol} / \mathrm{l}$ (S.E. \pm 1.93 ). On the other hand, the arterial blood glucose range from 4.79 and $8.84 \mathrm{mmol} / \mathrm{l}$ with a mean of $6.59 \mathrm{mmol} / \mathrm{l}$ (S.E. \pm 0.91 ), and the deep venous blood glucose range from 4.77 to $8.87 \mathrm{mmol} / \mathrm{l}$ with a mean of $6.76 \mathrm{mmol} / 1$ (S.E. $\pm 0.85)$.

In both groups, but mainly in the insulin-dependent one, spontaneous blood glucose variations were very high. In this group the mean arterio-deep venous glucose differences were positive in 4 instances and negative in 4 others, ranging from -0.88 to +0.38 $\mathrm{mmol} / \mathrm{l}$, the mean average being $-0.10 \mathrm{mmol} / \mathrm{l}$ (S.E. $\pm 0.17)$. The mean arterio-deep venous blood glucose differences of the insulin-independent diabetics were 2 positive and 2 negative, ranging from 0.95 to +0.15 $\mathrm{mmol} / \mathrm{l}$, the mean average being $-0.16 \mathrm{mmol} / \mathrm{l}$ (S. E. $\pm 0.19)$.

The 8 cases with insulin-dependent diabetes show forearm blood flow ranging from 2.09 to $5.62 \mathrm{ml} / \mathrm{min} /$ $100 \mathrm{ml}$ of forearm, with a mean of $3.25 \mathrm{ml} / \mathrm{min} / 100 \mathrm{ml}$ of forearm (S.E. \pm 0.43 ); while the 4 subjects with insulin-independent diabetes have forearm blood flow ranging from 2.74 to $3.56 \mathrm{ml} / \mathrm{min} / 100 \mathrm{ml}$ of forearm, the mean being $3.13 \mathrm{ml} / \mathrm{min} / 100 \mathrm{ml}$ of forearm (S.E. $\pm 0.18)$.

The mean average of the forearm glucose uptake is $-0.32 \mu \mathrm{mol} / \mathrm{min} / 100 \mathrm{ml}$ of forearm (S.E. \pm 0.59 ) 
Table 1.

Glucose

\begin{tabular}{|c|c|c|c|}
\hline \multirow[t]{2}{*}{ Cases } & Normals & $\begin{array}{l}\text { Insulin-Independent } \\
\text { Diabetics }\end{array}$ & $\begin{array}{l}\text { Insulin-Dependent } \\
\text { Diabetics }\end{array}$ \\
\hline & $\overline{22}$ & 5 & 8 \\
\hline Observations $\frac{+}{0}$ & $\begin{array}{l}67 \\
7 \\
25\end{array}$ & $\begin{array}{l}8 \\
1 \\
8\end{array}$ & $\begin{array}{l}22 \\
0 \\
19\end{array}$ \\
\hline $\begin{array}{l}\text { Arterial blood } \\
\text { mmoles } / 1\end{array}$ & $4.72 \pm 0.26$ & $6.59 \pm 0.91$ & $16.06 \pm 2$ \\
\hline $\begin{array}{l}\text { Deep venous blood } \\
\text { mmoles } / 1\end{array}$ & $4.55 \pm 0.26$ & $6.75 \pm 0.85$ & $16.16 \pm 1.93$ \\
\hline $\begin{array}{l}\text { Arterio-deep venous } \\
\text { differences mmoles } / 1\end{array}$ & $+0.17 \pm 0.21$ & $-0.16 \pm 0.19$ & $-0.10 \pm 0.17$ \\
\hline $\begin{array}{l}\text { Forearm blood flow } \\
\mathrm{ml} / \mathrm{min} / 100 \mathrm{ml} \text { of forearm }\end{array}$ & $3.11 \pm 0.22$ & $3.13 \pm 0.18$ & $3.25 \pm 0.43$ \\
\hline $\begin{array}{l}\text { Forearm glucose uptake } \\
\mu \mathrm{mol} / \mathrm{min} / 100 \mathrm{ml} \text { of forearm }\end{array}$ & $+0.53 \pm 0.20$ & $-0.50 \pm 0.23$ & $-0.32 \pm 0.59$ \\
\hline
\end{tabular}

\section{Phosphate}

\begin{tabular}{llll}
\hline Cases & 6 & - & 4 \\
\hline \multicolumn{1}{c}{+} & 11 & - & 4 \\
Observations 0 & 0 & - & 0 \\
& 2 & - & 3 \\
$\begin{array}{l}\text { Arterial blood } \\
\text { mmoles } / 1\end{array}$ & $0.40 \pm 0.04$ & - & $0.40 \pm 0.07$ \\
$\begin{array}{l}\text { Deep venous blood } \\
\text { mmoles/1 }\end{array}$ & $0.39 \pm 0.08$ & - & $0.41 \pm 0.01$ \\
$\begin{array}{l}\text { Arterio-deep venous } \\
\text { differences mmoles/1 }\end{array}$ & $+0.01 \pm 0.04$ & - & $-0.01 \pm 0.07$ \\
$\begin{array}{l}\text { Forearm blood flow } \\
\text { ml/min/100 ml of forearm }\end{array}$ & $3.16 \pm 0.35$ & - & $3.18 \pm 0.75$ \\
$\begin{array}{l}\text { Forearm phosphate uptake } \\
\mu \text { mol/min/100 ml of forearm }\end{array}$ & $0.03 \pm 0.04$ & - & $-0.03 \pm 0.13$ \\
\hline
\end{tabular}

\begin{tabular}{|c|c|c|c|c|}
\hline \multicolumn{5}{|c|}{ Potassium } \\
\hline Cases & 8 & & - & 4 \\
\hline Observations $\stackrel{+}{0}$ & $\begin{array}{l}5 \\
1 \\
13\end{array}$ & & $\begin{array}{l}- \\
-\end{array}$ & $\begin{array}{l}4 \\
1 \\
4\end{array}$ \\
\hline $\begin{array}{l}\text { Arterial blood } \\
\text { mmoles } / 1\end{array}$ & 4.1 & \pm 0.19 & - & $4.1 \pm 0.16$ \\
\hline $\begin{array}{l}\text { Deep venous blood } \\
\text { mmoles } / 1\end{array}$ & 4.4 & \pm 0.24 & - & $4.4 \pm 0.36$ \\
\hline $\begin{array}{l}\text { Arterio-deep venous } \\
\text { differences mmoles } / 1\end{array}$ & -0.3 & \pm 0.13 & - & $-0.3 \pm 0.32$ \\
\hline $\begin{array}{l}\text { Forearm blood flow } \\
\mathrm{ml} / \mathrm{min} / 100 \mathrm{ml} \text { of forearm }\end{array}$ & 3.1 & \pm 0.28 & - & $3.0 \pm 0.26$ \\
\hline $\begin{array}{l}\text { Forearm potassium uptake } \\
\mu \mathrm{mol} / \mathrm{min} / 100 \mathrm{ml} \text { of forearm }\end{array}$ & -0.93 & \pm 0.45 & - & $-0.90 \pm 2.7$ \\
\hline
\end{tabular}

for the insulin-dependent diabetics, and $-0.50 \mu \mathrm{mol} /$ $\min / 100 \mathrm{ml}$ of forearm (S.E. \pm 0.23 ) for the insulinindependent diabetics. The former group show values ranging from -2.85 to $+2.54 \mu \mathrm{mol} / \mathrm{min} / 100 \mathrm{ml}$ of forearm, and the latter from -2.82 to +0.56 .
The statistical elaboration of these figures shows that the difference between the two groups is significant $(p<0.02$, Fig. 3$)$.

c) Hyperthyroidism. The fasting arterial blood glucose concentration of this group range from 4.97 to 
$8.17 \mathrm{mmol} / \mathrm{l}(\mathrm{mean}=6.07 \mathrm{mmol} / \mathrm{l}, \mathrm{S} . \mathrm{E} . \pm 1.04)$ and the deep venous blood glucose concentration range from 4.85 to $7.86 \mathrm{mmol} / \mathrm{l}($ mean $=5.83 \mathrm{mmol} / \mathrm{l}, \mathrm{S}$. E. \pm 0.69$)$.

All mean arterio-deep venous glucose differences were positive, ranging from +0.03 to $+0.47 \mathrm{mmol} / \mathrm{l}$ $($ mean $+0.24 \mathrm{mmol} / \mathrm{l}, \mathrm{S} . \mathrm{E} . \pm 0.30)$.

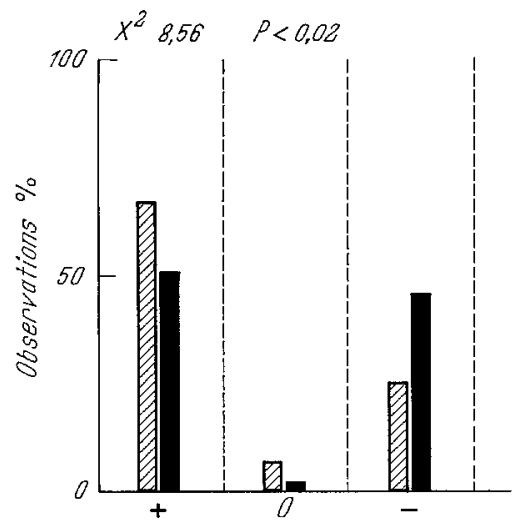

Fig. 3. Figure demonstrating statistically significant difference between the forearm glucose uptake of normals and diabetic patients By comparison between forearm glucose uptake observations of normals and diabetics it follows that in the former group $67.6 \%$ of observations are positive and $25.3 \%$ are negative, while in the latter groups $51.7 \%$ of observations are positive and $46.5 \%$ are negative

The forearm blood flow was above the normal range in all cases, showing variations from 5.48 to $9.70 \mathrm{ml} /$ $\min / 100 \mathrm{ml}$ of forearm (the mean being $6.96 \mathrm{ml} / \mathrm{min} /$ $100 \mathrm{ml}$ of forearm, S.E. \pm 1.77 ). In the two cases which have forearm blood flow above $6.5 \mathrm{ml} / \mathrm{min} /$ $100 \mathrm{ml}$ of forearm, the forearm glucose uptakes were above the normal range $(+3.01$ and $+3.09 \mu \mathrm{mol} / \mathrm{min} /$ $100 \mathrm{ml}$ of forearm). On the other hand, in the other two cases with forearm blood flow of 5.48 and $6.06 \mathrm{ml} /$ $\mathrm{min} / 100 \mathrm{ml}$ of forearm, the forearm glucose uptakes were in the normal range $(+0.23$ and $+0.70 \mu \mathrm{mol} /$ $\mathrm{min} / 100 \mathrm{ml}$ of forearm).

d) Hypothyroidism. In the two cases examined the fasting arterial blood glucose estimations were 3.97 and $3.16 \mathrm{mmol} / \mathrm{l}$ (mean $3.57 \mathrm{mmol} / \mathrm{l}, \mathrm{S} . \mathrm{E}$. \pm 0.40 ), while the deep venous blood glucose ones were 3.53 and $2.95 \mathrm{mmol} / \mathrm{l}$ (mean $3.24 \mathrm{mmol} / \mathrm{l}, \mathrm{S} . \mathrm{E}$. \pm 0.28 ).

The arterio-deep venous glucose differences were +0.44 and $+0.20 \mathrm{mmol} / 1$, with the mean of +0.33 $\mathrm{mmol} / \mathrm{l}$ (S.E. \pm 0.12 ).

The forearm blood flow were very low: 1.34 and $0.86 \mathrm{ml} / \mathrm{min} / 100 \mathrm{ml}$ of forearm, the mean being 1.10 $\mathrm{ml} / \mathrm{min} / 100 \mathrm{ml}$ of forearm (S. E. \pm 0.75 ). The forearm glucose uptakes were +0.59 and $+0.17 \mu \mathrm{mol} / \mathrm{min} /$ $100 \mathrm{ml}$ of forearm with the mean of $+0.36 \mu \mathrm{mol} / \mathrm{min} /$ $100 \mathrm{ml}$ of forearm (S.E. \pm 0.20 ).

\section{Forearm phosphate uptake}

a) Normals. Forearm phosphate and glucose uptakes were calculated on the same blood samples in 6 fasting normal subjects. For each subject at least two periods of observation were carried out.
In basal conditions the arterial blood phosphate concentration of this group ranges from 0.19 to 0.54 $\mathrm{mmol} / \mathrm{l}$, while the deep venous blood phosphate concentration ranges from 0.10 to $0.69 \mathrm{mmol} / \mathrm{l}$.

All periods of observation show positive arteriodeep venous phosphate concentration differences, except one case which has two negative periods of observation. The mean of the positive arterio-deep venous differences range from +0.008 to $0.12 \mathrm{mmol} / 1$, while the mean of the case with negative arterio-deep venous phosphate differences is $-0.17 \mathrm{mmol} / \mathrm{l}$.

The forearm blood flow of these cases range from 1.78 to $4.74 \mathrm{ml} / \mathrm{min} / 100 \mathrm{ml}$ of forearm. The mean of positive phosphate uptakes range from +0.02 to $+0.25 \mu \mathrm{mol} / \mathrm{min} / 100 \mathrm{ml}$ of forearm. On the other hand the mean average of the entire group is $+0.03 \mu \mathrm{mol} /$ $\min / 100 \mathrm{ml}$ of forearm (S.E. \pm 0.04 ).

b) Diabetics. Four cases with severe diabetes were examined. In this group arterial phosphate concentrations range from 0.18 to $0.52 \mathrm{mmol} / 1$, while the deep venous phosphate concentrations range from 0.23 to $0.57 \mathrm{mmol} / 1$. The arterio-deep venous blood phosphate differences were positive in 3 periods of observation, and negative in 4 periods ranging from -0.07 to $+0.04 \mathrm{mmol} / \mathrm{l}$.

The forearm blood flow measurements range from 1.74 to $6.11 \mathrm{ml} / \mathrm{min} / 100 \mathrm{ml}$ of forearm.

The mean average of the forearm phosphate uptake is $-0.03 \mu \mathrm{mol} / \mathrm{min} / 100 \mathrm{ml}$ of forearm (S.E. \pm 0.13 ). The mean values ranging from -0.06 to $+0.25 \mu \mathrm{mol} /$ $\mathrm{min} / 100 \mathrm{ml}$ of forearm.

\section{Forearm potassium uptake}

a) Normals. Eight subjects were examined for 19 periods of observation. The mean arterial plasma potassium concentration values range from 3.10 to $4.80 \mathrm{mmol} / \mathrm{l}$, while the mean values of deep venous plasma potassium concentration range from 3.22 to $5.06 \mathrm{mmol} / \mathrm{l}$. The arterio-deep venous plasma potassium concentration differences were negative in 13 periods of observation with values ranging from -0.05 to $2.10 \mathrm{mmol} / 1,0$ in one case and positive in 5 others. The last periods of observation show values ranging from +0.10 to $+0.35 \mathrm{mmol} / \mathrm{l}$. The forearm blood flow of this group range from 1.55 to $4.74 \mathrm{ml} / \mathrm{min} / 100 \mathrm{ml}$ of forearm. Consequently the mean values of the forearm potassium uptake are negative in 7 cases, zero in one and positive in one. The former range from -0.51 to $-3.07 \mu \mathrm{mol} / \mathrm{min} / 100 \mathrm{ml}$ of forearm, while the latter is $+1.15 \mu \mathrm{mol} / \mathrm{min} / 100 \mathrm{ml}$ of forearm. The mean average of this group is $-0.93 \mu \mathrm{mol} / \mathrm{min} /$ $100 \mathrm{ml}$ of forearm (S. E. $\pm 0,45)$.

b) Diabetics. Four cases were investigated. The mean arterial plasma potassium concentration range from 3.83 to $4.45 \mathrm{mmol} / \mathrm{l}$, while the mean deep venous plasma potassium range from 3.73 to $5.52 \mathrm{mmol} / \mathrm{l}$. The positive arterio-deep venous potassium concentration differences are +0.10 and $+0.42 \mathrm{mmol} / 1$ and the negative ones are -1.07 and $-0.52 \mathrm{mmol} / 1$. 
The forearm blood flow of this group range from 1.74 to $6.11 \mathrm{ml} / \mathrm{min} / 100 \mathrm{ml}$ of forearm, and the forearm potassium uptakes are $+2.11,+0.22,-2.42$ and $-1.30 \mu \mathrm{mol} / \mathrm{min} / 100 \mathrm{ml}$ of forearm with a mean average of $-0.90 \mu \mathrm{mol} / \mathrm{min} / 100 \mathrm{ml}$ of forearm (S.E. \pm 2.7 ).

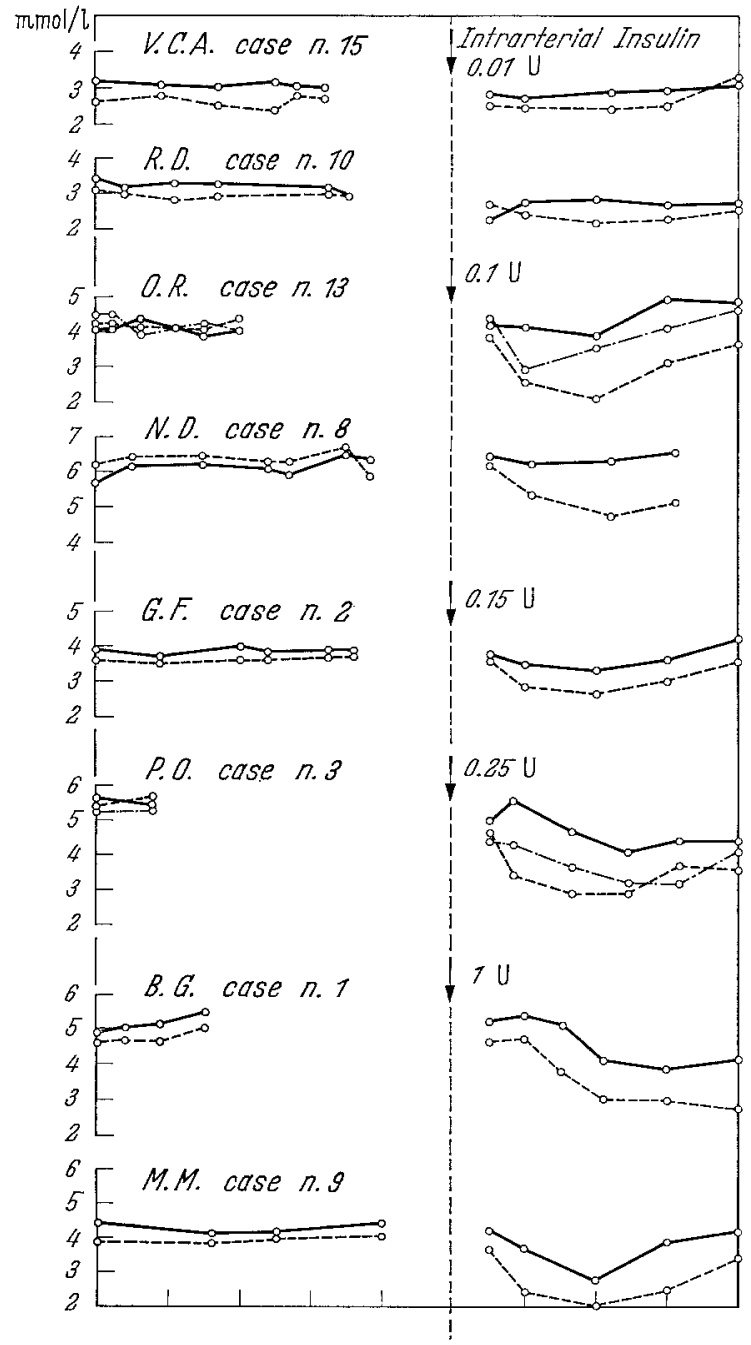

Fig. 4. The effect of insulin injected into the brachial artery of normal subjects in amounts $0.01,0.1,0.25,1.0$ Units

The arterial blood glucose is not depressed by doses of insulin of less than 0.15 Units, while the deep venous blood glucose is depressed by doses of 0.1 Units and the arterial blood glucose is unmodified. Both the arterial and deep venous blood glucose are depressed by insulin doses greater than 1.0 Unit

4. Effect of glucagon-free insulin introduced into the brachial artery on forearm glucose uptake

a) Normals. Fig. 4 shows that only 0.1 units of glucagon-free insulin introduced into the brachial artery is followed by a progressive decrease of the deep venous blood glucose of the forearm, while the systemic arterial blood glucose remains unaffected. These findings are obtained in two cases. Greater doses of $0.15,0.25$ and 1 unit of glucagon-free insulin, decrease sinultaneously both systemic arterial and deep venous blood glucose of the forearm, though the latter always in a more marked way. The forearm uptakes are increased in all the experimentes and last for over 40 minutes. In 5 cases the forearm blood flow is also augmented. Smaller doses of 0.01 of glucagonfree insulin do not change either the forearm glucose uptakes, or the forearm blood flows.

b) Diabetics, 1.0 unit of glucagon-free insulin introduced into the brachial artery of 2 insulindependent diabetics is followed by no significant changes in the forearm glucose uptakes. Before insulin the systemic arterial and the deep venous blood glucose of the forearm were very unstable in both cases, as well as the forearm glucose uptakes. After insulin the arterial blood glucose is always lower than the deep venous blood glucose and both keep decreasing throughout the period of the experiment $(40-$ 50 minutes) (Fig. 5).

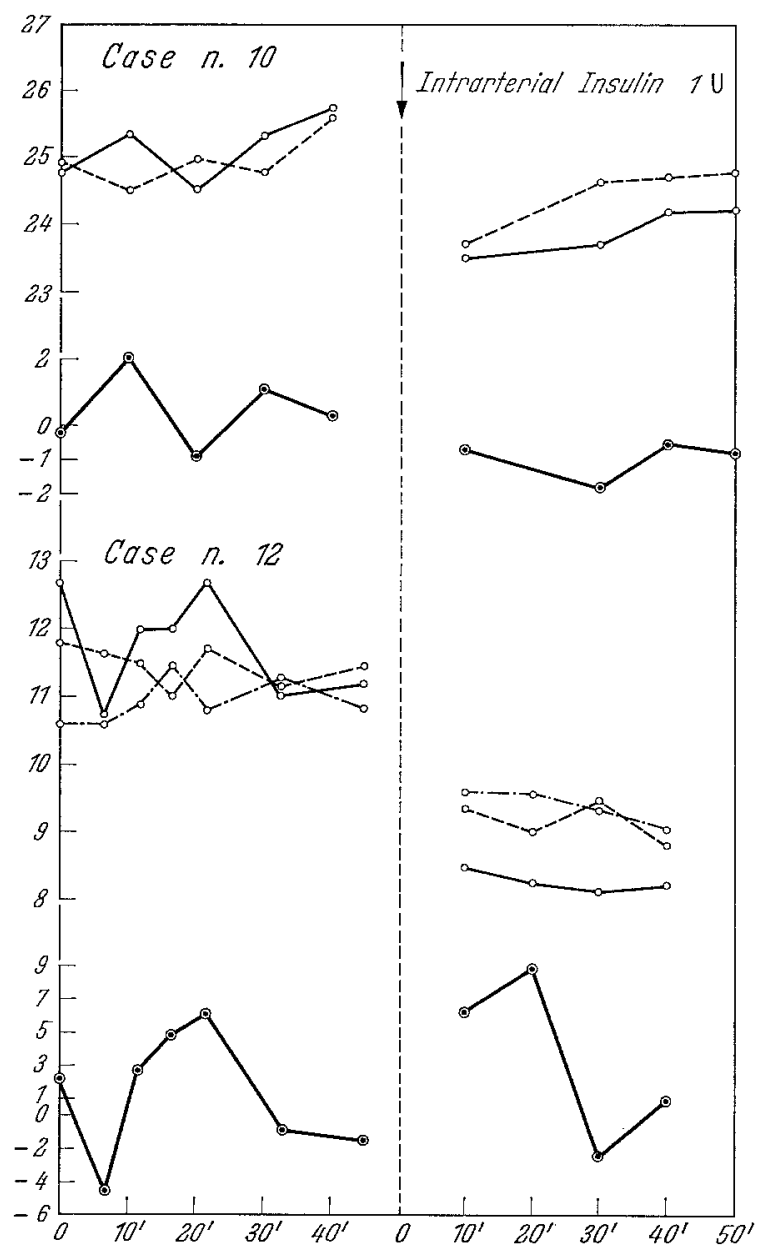

Fig. 5. Figure demonstrating that the arterial blood glucose, the deep venous blood glucose of the forearm, and the forearm glucose uptake of two insulindependent diabetics before and after intrarterial insulin are very unstable and that after 1.0 Unit of glucagon-free insulin the arterial blood glucose is always lower than the deep venous blood glucose

In a third insulin-dependent diabetic the forearm glucose uptake increases after 1.0 unit of glucagonfree insulin. It is noteworthy that the systemic arterial 
blood glucose in basal conditions is lower than the deep venous blood glucose of the forearm, showing a negative forearm glucose uptake, and also that after insulin, although the systemic arterial blood glucose keeps decreasing, the deep venous blood glucose is lower than the arterial blood glucose for over $30 \mathrm{mi}$ nutes. Then the values inverted (Fig. 6). After insulin the forearm blood flow decreases in the former 2 cases and increase in the latter one. After 4 units of glucagonfree insulin similar, though more marked effects, are observed in a fourth insulin-dependent diabetic.

After 0.25 units of glucagon-free insulin, the insulin-dependent diabetic does not show any significant changes of the forearm glucose uptake, which keeps decreasing for the entire period of the experiment.
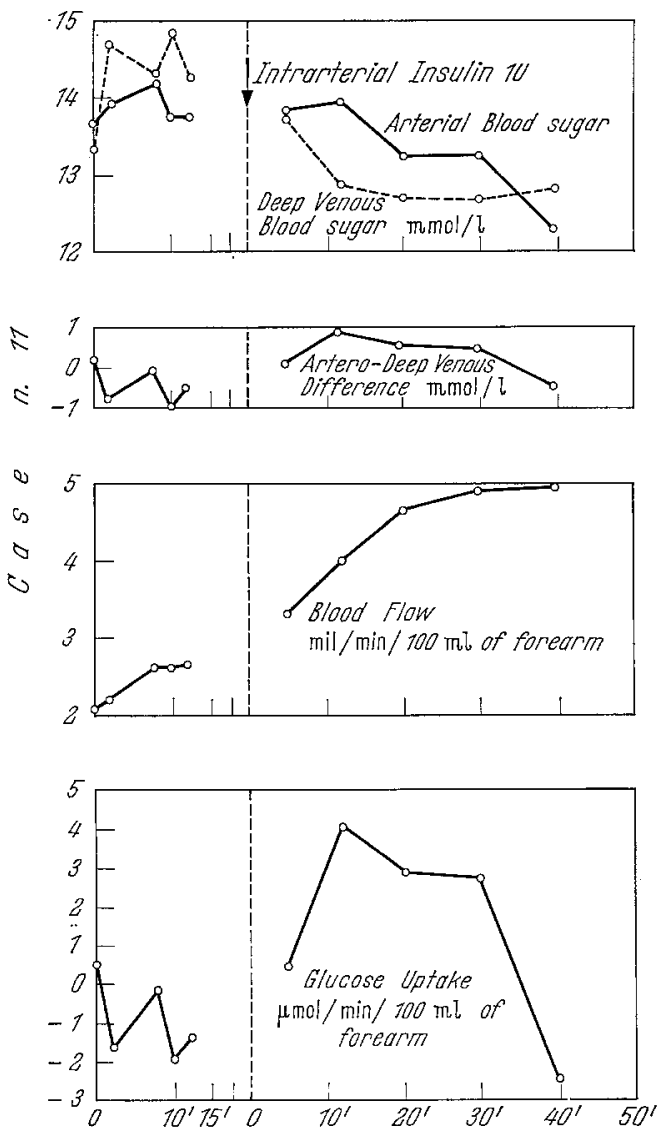

Fig. 6. Figure demonstrating that after $1.0 \mathrm{Unit}$ insulin the forearm glucose uptake of an insulin-dependent diabetic inereases, while the systemic arterial blood glucose continues to diminish and the forearm blood flow increases

On the other hand, in an insulin-independent diabetic patient the introduction of the same dose of insulin gives a very marked increase of the forearm glucose uptake similar to that obtained in normal patients with a dosage of 0.1 units of glucagon-free insulin, while the systemic arterial blood glucose is considered to be unaffected because its rate of fall was the same before and after insulin (Fig. 7).
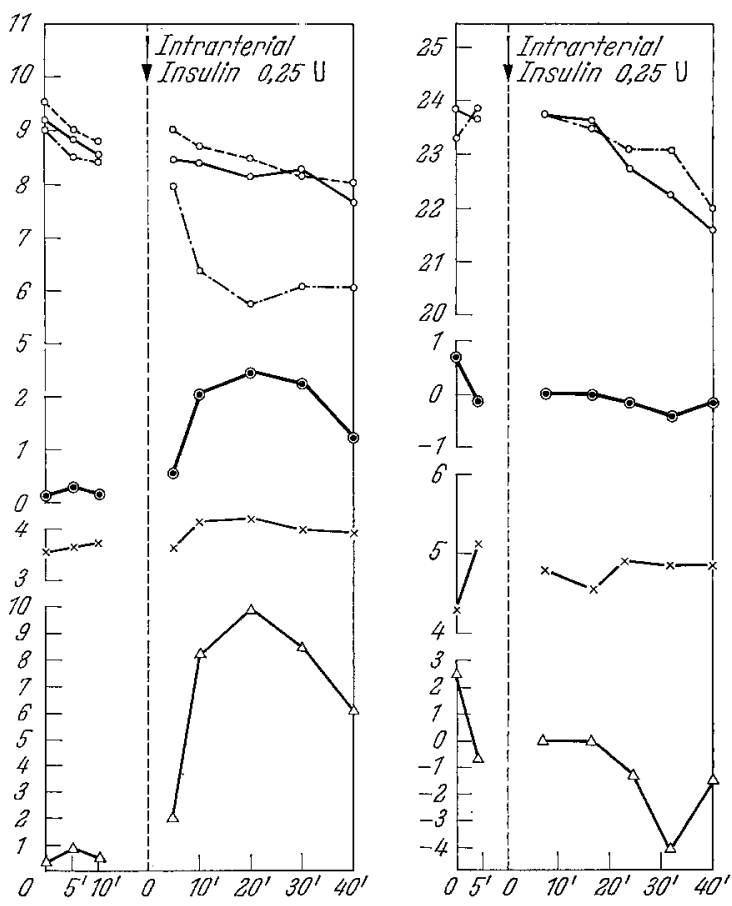

Fig. 7. The injection of 0.25 Units of glucagon-free insulin into the brachial artery is followed in the insulin-independent diabetic by an increase of the forearm glucose uptake due only to a decrease of the homo-lateral deep venous blood glucose (left), while in the insulin-dependent diabetic both the arterial blood glucose and the deep venous blood glucose of the homolateral forearm keep diminishing, and the forearm glucose uptake as well shows negative figures for the entire period of the experiment (right)

\section{Discussion and Conclusions}

\section{Technical considerations}

Our results show that the human forearm is a suitable experimental preparation for investigations on peripheral metabolism in vivo.

Quantitative metabolic data per minute and per substrate volume can be calculated from the arterial and deep venous blood concentration differences and the blood flow according to the Fick principle, because the estimations of these three parameters can be carried out simultaneously and easily in the human forearm.

As far as glucose metabolism is concerned spontaneous changes of the above 3 factors were documented and therefore methods for their rapid determination were needed.

The venous occlusion plethysmographic technique was chosen in order to measure rapid variations of forearm blood flow. We used an electric transducer, which produces better results than the mechanical recording. The last is biased by the compressibility of the air and is unable to fit the detector sensitivity to different working conditions.

We did not use the dye-dilution technique employed by the Andres group working in similar metabolic investigations for the following reasons: 1 . this method does not measure rapid changes of the forearm blood 
flow; 2. it is always very difficult to obtain a complete mixing between the injected dye and the blood; 3 . hemolysis is very frequent; and finally 4 . this technique does not seem to be suitable for repetitive measurements of the forearm blood flow.

As the human forearm is a heterogeneous organ formed by different tissues (skin, adipose tissue, bone and connective tissue) it becomes difficult to evaluate separately the forearm muscular blood flow from the total forearm blood flow. However it should be stressed that the blood flow of the bone, fat and connective tissues is negligible compared with the cutaneous and muscular blood flows (EDHoum et al., 1945; Cooper et al., 1955). The total forearm blood flow can be accounted for by both the cutaneous and the muscular blood flow of the forearm. On the other hand, no reliable techniques are available to separate cutaneous from muscular blood flow of the forearm for these metabolic estimations. HEJL et al. (1959) made an attempt to measure separatly the two components by difference: the total forearm blood flow by means of plethysmography and the cutaneous blood flow using the calorimetric technique. They found that the muscular blood flow of the forearm is $2 / 3$ of the total forearm blood flow.

CoOper et al. (1955) measured the forearm blood flow before and after adrenaline jontophoresis in order to suppress the cutaneous blood flow and established the following relationship between muscular and total forearm blood flow:

muscular blood flow $=0.47 \times$ total blood flow +0.83 if the values of the total blood flow are not more of $5.6 \mathrm{ml} / \mathrm{min} / 100 \mathrm{ml}$ of forearm.

Our results should also be regarded as expressions mainly of muscular metabolism of the forearm, because in all the experiments the venous blood sampling was always carried out by means of a catheter fixed in the deep venous territory of the forearm draining blood from the muscular tissue. Although there are numerous anastomoses between superficial veins and the deep veins, the catheter placed in the latter territory drains blood from the skeletal muscles without any significant contamination with the cutaneous blood. This contamination can occur, however, when one applies $50-70 \mathrm{mmHg}$ pressure above the elbow for the estimation of the forearm blood flow (BALTZaN et al., 1962). In order to avoid the mixing of the muscular blood with the cutaneous blood we found that the interval between the end of the forearm blood flow measurement (2) and the blood sampling (3) allows the blood eventually contaminated to be discharged from the experimental preparation.

The changes of the forearm blood flow due to the Cournand's needle and the catheter in the deep venous territory are negligible when the experimental forearm set up is stabilized.

As far as blood glucose estimations are concerned the glucose-oxidase method of HugGETT and Nixon
(1957) has provided a suitable technique both for the determination of the very small arterio-venous glucose differences, and for detecting "true" blood sugar and not other reducing compounds which can alter the final results.

Finally it is to be emphasized that the experimental forearm preparation works efficiently if the following conditions are met:

1. at least 5 very well trained persons familiar with all the steps of the procedure used in the experimental forearm set up;

2. a room with relative thermic equilibrium;

3. meticulous preliminary checking of all the instruments.

Provided that the above conditions are met the frequency of success of these estimations in our hands is of 2 out of 3 , the main problem being placement of the catheter in a deep vein.

\section{The forearm glucose uptake}

The calculated means of the forearm glucose uptakes indicate that there are significant differences between the normal subject and both the insulindependent and the insulin-independent diabetic patients. The normal group has a mean average forearm glucose uptake of $+0.53 \mu \mathrm{mol} / \mathrm{min} / 100 \mathrm{ml}$ of forearm (S.E. \pm 0.20 ) which is similar to the value calculated by BALTzAN et al. (1962) ( $+0.52 \mu \mathrm{mol} / \mathrm{min} / 100 \mathrm{ml}$ of forearm, S.E. \pm 0.075$)$. This group used for the determination of the forearm blood flow the constant injection indicator-dilution method (Evans blue dye) instead of the plethysmographic technique employed in the present work.

On the other hand both the diabetic groups have negative mean averages of the forearm glucose uptakes the insulin-dependent diabeties $-0.32 \mu \mathrm{mol} / \mathrm{min} / 100$ $\mathrm{ml}$ of forearm (S.E. \pm 0.59 ) and the insulin-independent ones $-0.50 \mu \mathrm{mol} / \mathrm{min} / 100 \mathrm{ml}$ of forearm (S.E. $\pm 0.23)$. These findings are substantiated by the fact that out of 99 periods of observation of the control group 67 are positive, 7 are 0 and 25 are negative, while out of 58 periods of observation of both the diabetic groups 30 are positive, 1 is 0 and 27 are negative.

The positive forearm glucose uptakes prevailing in the normal group should mean that the peripheral tissues of the subject in fasting and resting conditions, take up glucose from the circulation in the calculated amount which satisfy their basal metabolic needs.

On the other hand, the negative forearm glucose uptakes found mostly in the diabetic group are more difficult to explain. It is well established that skeletal muscles lack glucose-6-phosphatase (LILIENTHAL and ZIERLER, 1957), and therefore this tissue is unable to produce glucose, not as on the contrary of what the negative forearm glucose uptakes would suggest.

ButTeRfIELD and HoLLING (1959) facing the same interpretative problem put forward the hypothesis 
of a muscular adaptation enzyme, present in such minute amounts as to be not yet detectable, which may be responsible for the glucose yield from the skeletal muscles of the diabetics.

ZIERLER and ANDRES (1956) interpreted the negative arterio-venous glucose differences detected in normal subjects as due to the reciprocal exchange of the glucose molecule between the arterial and the interstitial compartments when the arterial blood glucose is above or below $4.7 \mathrm{mmol} / \mathrm{l}$.

In our previous report we proposed that the negative arterio-deep venous glucose differences of the forearm may be due to a glucose output from the fat tissue (Altilla et al., 1964). However this problem remains to be solved.

The following further points have to be made:

a) the arterial and the forearm deep venous blood glucose vary spontaneously;

b) these fluctuations are wider in the diabetic group than in the normal group and mainly in the insulindependent diabetics.

These blood glucose variations are so broad in the diabetic group that they cannot be refered to the error of the blood glucose determination, because the method of $\mathrm{HvG}$ GETT and NIXON (1957) that we have used has, in our hands, the same standard error both for low and high blood glucose concentrations. It is reasonable to assume that the findings in the diabetics are caused by the dissociation between the hepatic glucose output and the peripheral glucose utilization particularly accomplished in the insulin-dependent diabetics where plasma insulin is low or absent (Berson and YaLOW, 1962).

Rapid and spontaneous changes of the forearm blood flow have also been shown in all groups of patients. However these variations were particularly wide in the hyperthyroid patients who also showed the highest values of the forearm blood flow.

It has been recently demonstrated that in these patients either the cutaneous component or the muscular one of the forearm blood flow has the same increment (KonTos et al., 1965).

Therefore the forearm blood flow of the normals and of both the diabetics groups with values in between the hyperthyroid and the hypothyroid patients can be accepted as a reliable hemodynamic parameter for the calculation of the forearm glucose uptakes.

Finally it is noteworthy that the statistical elaborations of our data indicate that in 3 insulin-dependent diabetics with very wide fluctuations of both the arterial and the deep venous blood glucose concentrations, were found positive significant correlations between the arterial blood glucose and the forearm glucose uptake, while no correlations were detected between the deep venous blood glucose and the forearm glucose uptake.

These calculations confirm the previous observations of ButTerfield and Holling (1959) demonstrating that there is an arterial blood glucose concentration (tissue glucose threshold), above which glucose switches from the extracellular space to the intracellular compartment.

In figure 8 these statistical calculations are presented.

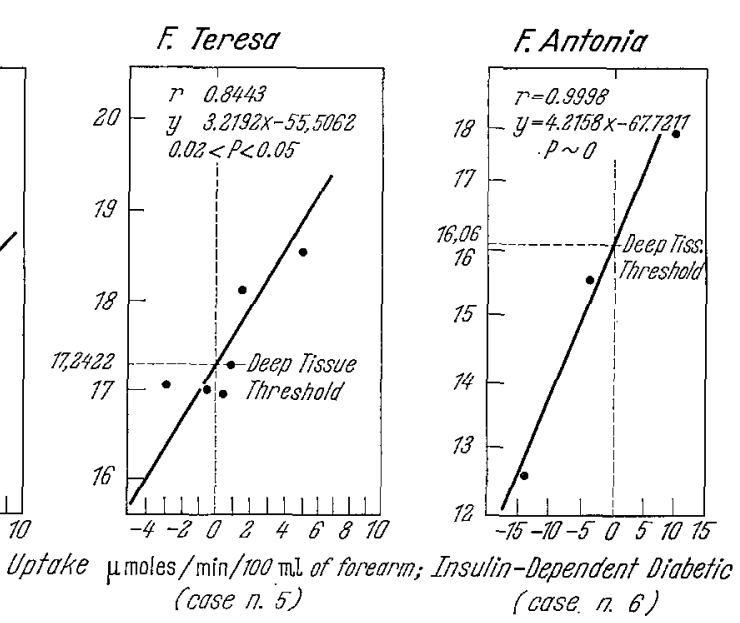

(case n. 6)

alucose uppatient

\section{The forearm phosphate and potassium uptakes}

CHEFTAMI (1963) showed that the plasma phosphate fall after insulin is related to the increased muscular glucose uptake. This correlation was first demonstrated by LEVINE et al. (1949) in animal experiments, even though the fate of the phosphate after its muscular uptake is still unknown.

The present work demonstrates for the first time that in man in vivo there is a statistically significant correlation between forearm phosphate and glucose uptakes both in normal subjects and in the diabetic groups, giving further evidence for the above statement (ZAMPA et al., 1964).

In addition it should be noted that the calculated slope for the diabetic is more downward inclined than that of the normals, indicating a reduced forearm glucose uptake, because in these patients the plasma insulin is low or absent (Fig. 9).

These statistical calculations show that the forearm phosphate uptake follows the forearm glucose uptake as an index of the peripheral glucose utilization. According to Mruls and Thomas (1959) any variations of the muscular-plasma phosphate equilibrium depend upon the phosphate uptake or the phosphate output of the skeletal muscles.

As far as forearm potassium uptake, our statistical 
calculations excluded any significant correlation to the forearm glucose uptake both in normals and in diabetics.

It is however noteworthy that during the periods of our experiment performed between 10 a.m. and 1 p. $\mathrm{m}$. there were negative forearm potassium uptakes indicating that potassium comes out of the muscular cells mainly in normal subjects.

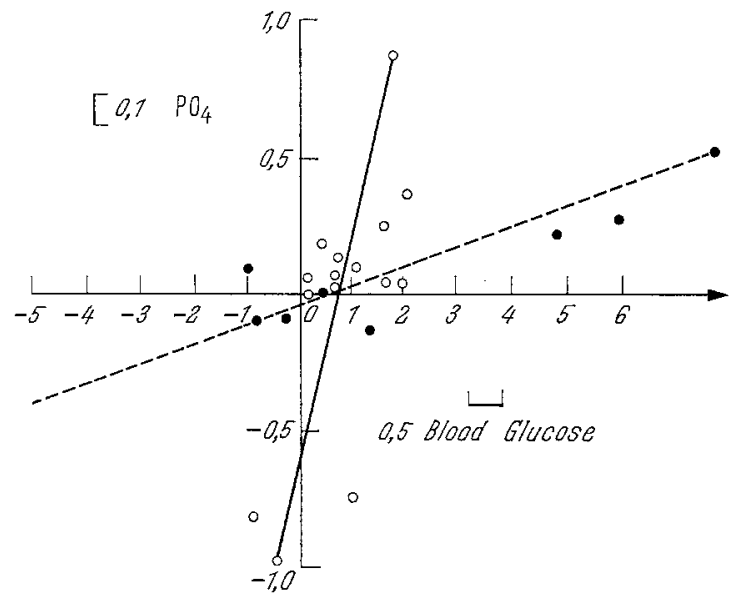

Fig. 9. The statistically significant relationship between forearm phosphate uptake and forearm glucose uptake both of normals (unbroken line) and of diabetics (broken line)

4. Effect of intra-arterial insulin on forearm glucose metabolism.

Our investigations have showed that intra-arterial insulin administration increases the glucose uptake of the directly perfused area, without affecting the systemic arterial blood glucose.

The increased forearm glucose uptake after intraarterial insulin is caused by the selective reduction of the deep venous blood glucose of the forearm, which in turn is produced by the administration of 0.1 units of glucagon-free insulin, which is unable to affect the systemic blood glucose.

Greater dosage of glucagon-free insulin decreases both the deep venous blood of the forearm and the systemic blood glucose, and masks the ability to distinguish between the insulin effect on the peripheral tissue from that on the liver (inhibition of the hepatic glucose output).

On the other hand, in the insulin-dependent diabetics no peripheral insulin effect was noted using the same or higher insulin doses which were efficient in the normal subject.

The intra-arterial administration of $0.25-1.0$ units of insulin was unable to increase the forearm glucose uptake in 3 insulin-dependent diabetics and in the 4th one only a very slight effect was detected between the 10th and 30 th minutes of the experiment. Further increase of the insulin dosage up to 4 units was followed not only by the increase of the forearm glucose uptake but also by the decrease of the systemic blood glucose which is due to the hepatic inhibition of glucose output caused by insulin.

In the insulin-independent diabetes, the intra-arterial administration of 0.25 units of insulin caused the typical selective increase of the forearm glucose uptake without affecting the systemic blood sugar, as 0.10 units of insulin did in the normal subject.

These experimental observations suggest that the insulin-dependent diabetic may have a peripheral tissue resistance to the insulin action, while the insulinindependent diabetic behaves as the normal, even if it necessitates greater doses of insulin in order to obtain the same effect.

The mechanism of the peripheral tissue resistance to the insulin effect of the insulin-dependent diabetics is unknown, however ButTERFIELD et al. (1963) suggest that the skeletal muscles of the juvenile diabetic fix insulin less efficiently than normals do, accounting for the lack of increasing forearm glucose uptake of these subjects.

Another possible interpretation can be related to an unknown insulin antagonist in the peripheral blood.

Finally we should like to stress that in the insulin -dependent diabetics the systemic arterial blood glucose fall is proportional to the dose of insulin, while the deep venous blood glucose of the forearm behaves independently. This would suggest that in these subjects the liver is normally sensitive to insulin while the peripheral tissue is not, causing the dissociation of the hepatic glucose output from the peripheral utilization.

This interpretation can account for the instability of the blood glucose of the insulin-dependent diabetics; as ButTERFIELD and WhICHELOW (1965) have already indicated for juvenile diabetics.

\section{References}

Abramson, D.I., and E.B. Ferris jr.: Responses of blood vessels in the resting hand and forearm to various stimuli. Amer. Heart J. 19, $541-553$ (1940).

Andres R., K.L. Zierler, H.M. Anderson, W.N. Stainsby, G. CAdER, A.S. GHRA Yyib and J.L.LIIIENTHAL jr.: Measurement of blood flow and volume in the forearm of man; with notes on the theory of indi. cator dilution and on production of turbulence, hemolysis and vasodilatation by intravascular injection. $J$. clin. Invest. 33, $482-504$ (1954).

- G. CADER and K.L. ZTERLER: The quantitatively minor role of carbohydrate in oxidative metabolism by skeletal muscle in intact man; measurements of oxygen and glucose uptake and carbon dioxide and lactate production in the forearm. J. clin. Invest. 35, $671-682$ (1956).

Altilia, F., D. Bracchettri, M. Massari e G.A. Zampa: La valutazione quantitativa del ricambio glicidico del muscolo scheletrico nell'uomo. Nota $2^{\circ}$ : La estrazione muscolare del glucosio in condizioni di base nel soggetto normale e nel diabete mellito. Rilievi preliminari sull'effetto insulinico nella muscolatura scheletrica. Rass. Fisiopat, clin. ter. 36, 309-331 (1964).

Baltzan, M.A., R. Andres, G. CADer and K.L. Zierler Heterogenity of forearm metabolism with special reference to free fatty acids. J. clin. Invest. 41, 116-125 (1962). 
Berson, S.A., and R. S. YALOW: Immunoassay of plasma insulin. Immunoassay of Hormones. Ciba Foundation Colloquia on Endocrinology. 14, 182-200 (1962).

Butrerfield, J.H., and H.E. Holima: Peripheral glucose metabolism in fasting control subjects and diabetic patients. Clin. Sci. 18, 147-174 (1959).

Butterfield, W.J.H., C.J. Garratt and M.J. WhicheLow: Peripheral hormone action: studies on the clearance and effect of $\left(\mathrm{I}^{131}\right)$ iodo insulin in the peripheral tissues of normal, acromegalic and diabetic subjects. Clin. Sci. 24, 331-341 (1963).

- and M.J. WHICHELow : Peripheral glucose metabolism in control subjects and diabetic patients during glucose, glucose-insulin and insulin-sensitivity test. Diabetologia $1,43-53(1965)$.

Chestam, H.D.: The action of insulin on the blood potassium and phosphate in endocrine disorders. Clin. Sci. 24, 29-37 (1963).

Cooper, H.E., O.G. Enholm and R.F. Mottram: The blood flow in skin and muscle of the human forearm. J. Physiol. (London) 128, 258-267 (1955).

Enholim, O.G., S. Howarth and J. MoMicratel : Heart failure and bone blood flow in osteitis deformans. Clin. Soi. 5, 249-260 (1945).

Fiske, C.H., and Y. Subbarow: The colorimetric determination of Phosphorus. J. biol. Chem. 66, 375-400 (1925).

Greenfield, A.D.M., and G.C. Pattersox: A simple water-filled plethysmograph for the hand and forearm with temperature control. J. Physiol. (London) 123, $629-649$ (1954)

HeJt, Z., J. Jirka, I. Modlapolisck and J. Brod: Change of blood flow in forearm muscle and skin during an acute emotional stress (mental arithmetic). Clin. Sci. 18, $491-498(1959)$.

HugGeTt, A.St., and D. A. Nixon: Use of glucose oxydase, peroxidase and $\mathrm{O}$-dianiside in determination of blood and urinary glucose. Lancet 1957 II, $368-370$.

Kon'sos, H.A., W. ShaptRo., H.P. Mavok jr., D.W. Richardoson, J.L. Pexterson jr. and A.R. Sharpe jr.:
Mechanism of certain abnormalities of the circulation to the Limbs in Thyrotoxicosis. J. clin. Invest. 44, $947-956(1965)$

Levine, R., P.D. Loube and H.F. Wetsberg: Nature of action of insulin on level of serum inorganic phosphate. Amer. J. Physiol. 159, 107-110 (1949).

Liliminthat, J.L., and K.L. ZterLeR: Disease of muscle. In: Thompson, R.H.S., and E. KING:Biochemical disorders in human disease. Ed. J. \& A. ChURChIm Ltd. London, 1957.

Mottram, R.F., and W.J.H. ButTERFIELd : The human forearm as a preparation for metabolic investigation. Proc. roy. Soc. Med. 54, 549-552 (1961).

Milus, J.N., and S. Tromas: The influence of adrenal corticoids on phosphate and glucose exchange in muscle and liver in man. J. Physiol. 148, 227-239 (1959) Zampa, G.A., F. Altilia, E. Borgatti, E. Pascucct, E. Fiore e B. Magnani: Applicazioni della pletismografia ad occlusione venosa alla ricerca emodinamica e metabolica. Boll. Soc. ital. Biol. sper. 39, 263-266 (1962a).

- - - D. Bracchetti e F. Fiore: La valutazione del ricambio glicidico del muscolo scheletrico nell'uomo. Nota $I$ : Tecnica e risultati preliminari. G. Clin. med. 43, $1489-1518(1962 b)$

- G.D. Geminlani, D. Bracchetti, E. Borgatti e F. AtTilia: La valutazione quantitativa del ricambio glicidico nel muscolo scheletrico nell'uomo. Nota III : Correlazione tra dinamica tissutale del fosforo e del potas. sio e captazione del glucosio a livello del l'avambraccio nel soggetto normale e nel diabete mellito. G. Clin. med. 43, 995-1012 (1964)

ZiERLER, K.L., and R. ANdRES: Carbohydrate metabolism in intact skeletal muscle in man during the night. J. clin. Invest. 35, 991-997 (1956).

Dr. G.A. ZAMPA

The Institute of Medical

Pathology of the Bologna Univ.

S. Orsola Hospital

Bologna, Italia 